\title{
Atmospheric patterns driving Holocene productivity in the Alboran Sea (Western Mediterranean): A multiproxy approach
}

\author{
Blanca Ausín,' Jose A Flores,' 'Francisco J Sierro,' Isabel Cacho, ${ }^{2}$ \\ Iván Hernández-Almeida, ${ }^{3}$ Belén Martrat ${ }^{4}$ and Joan $O$ Grimalt $^{4}$
}

\begin{abstract}
High-resolution paleoproductivity variations have been reconstructed in a productive cell in the Alboran Sea for the Holocene. Fossil coccolithophore assemblages have been studied along with the $\mathrm{U}_{37}^{k^{\prime}}$-estimated sea-surface temperature (SST) and other paleoenvironmental proxies. The appearance of this cell is suggested at $7.7 \mathrm{ka}$ cal. BP and was linked to the establishment of the western anti-cyclonic gyre. From that time until the present, the nannofossil accumulation rate of Florisphaera profunda has revealed successive episodes of weakening and strengthening of upwelling conditions in the Alboran Sea that have been simultaneous to changes in Western Mediterranean Deep Water (WMDW) formation in the Gulf of Lions. A two-phase scenario operating at millennial-centennial time scale is proposed to explain this climatic and oceanographic variability: (I) coeval with more arid climate conditions, weaker northerlies or north-westerlies blowing over the Gulf of Lions would have triggered a slackening of WMDW formation. This together with a minor Atlantic let (AJ) inflowing into the Alboran Sea would have led to less vertical mixing and, hence, a more stable water column in the study area; (2) wetter climate conditions would have prevailed in the region, while stronger northerlies or north-westerlies would have enabled WMDW reinforcement in the Gulf of Lions simultaneous to an intensification of the $\mathrm{AJ}$ that migrated southward. This would have increased vertical mixing, intensifying upwelling conditions in the study area. Here, the winter North Atlantic Oscillation (NAO) is considered to be an important forcing mechanism for this variability, influencing WMDW formation, which in turn has been linked to short-term productivity variations during the last $7.7 \mathrm{ka}$ in the Alboran Sea.
\end{abstract}

\section{Keywords}

Alboran Sea, coccolithophore productivity, Holocene, North Atlantic Oscillation, Western Mediterranean Deep Water

Received 3 June 20I4; revised manuscript accepted I3 November 2014

\section{Introduction}

In recent years, climatic variability during the Holocene (11.7 ka to the present) has been a challenging issue. Recent studies have shown that this period has been characterised by several abrupt climatic events as well as pervasive short-term oscillations (Mayewski et al., 2004; Wanner et al., 2011), ruling out the perception of the Holocene as having been stable. As the most recent geological period, the variability recorded by the natural system during this time must be taken into account when attempting to project future climatic scenarios (IPCC, 2013). Identifying the causes of this variability, as well as the mechanisms transferring it from one region to another, is crucial if we are to gain an overall understanding of the system.

The Western Mediterranean is an essential region as regards determining climatic teleconnections with the North Atlantic area (Cacho et al., 1999; Martrat et al., 2004; Sierro et al., 2005). Current sea-level, temperature and precipitation variability in the Western Mediterranean have been linked to the fluctuation of the atmospheric gradient formed by the Azores high-pressure and the Icelandic low-pressure centres: the North Atlantic Oscillation (NAO; Lionello et al., 2006; Tsimplis and Josey, 2001), a natural mode of atmospheric variability that has a pronounced effect on the climate of western central Europe at decadal time scales (Hurrell, 1995). The intensity of a NAO-like pattern has already been suggested as a likely driving mechanism for several short-term environmental oscillations in the Western Mediterranean during the Holocene (Fletcher and Zielhofer, 2011; Fletcher et al., 2012; Frigola et al., 2007; Goy et al., 2003; Jalut et al., 1997, 2000). However, little evidence is available concerning the impact of short-term climatic oscillations on past ocean productivity in the Mediterranean Sea (Lionello, 2012) or regarding its probable connection with North Atlantic climatic processes. Within the generalised oligotrophic character of the Mediterranean Sea, the Alboran Sea is considered an exception, exhibiting quasi-permanent areas of upwelling (Sarhan et al., 2000) where local vertical mixing is the main factor controlling marine productivity (Dafner et al.,

'Department of Geology, University of Salamanca, Spain

2Department of Stratigraphy, Paleontology and Marine Geosciences, University of Barcelona, Spain

${ }^{3}$ Institute of Geography and Oeschger Centre for Climate Change Research, University of Bern, Switzerland

${ }^{4}$ Department of Environmental Chemistry, Institute of Environmental

Assessment and Water Research, Barcelona, Spain

\section{Corresponding author:}

Blanca Ausín, Department of Geology, University of Salamanca, Plaza de la Merced s/n, 37008 Salamanca, Spain.

Email: b_ausin@usal.es 

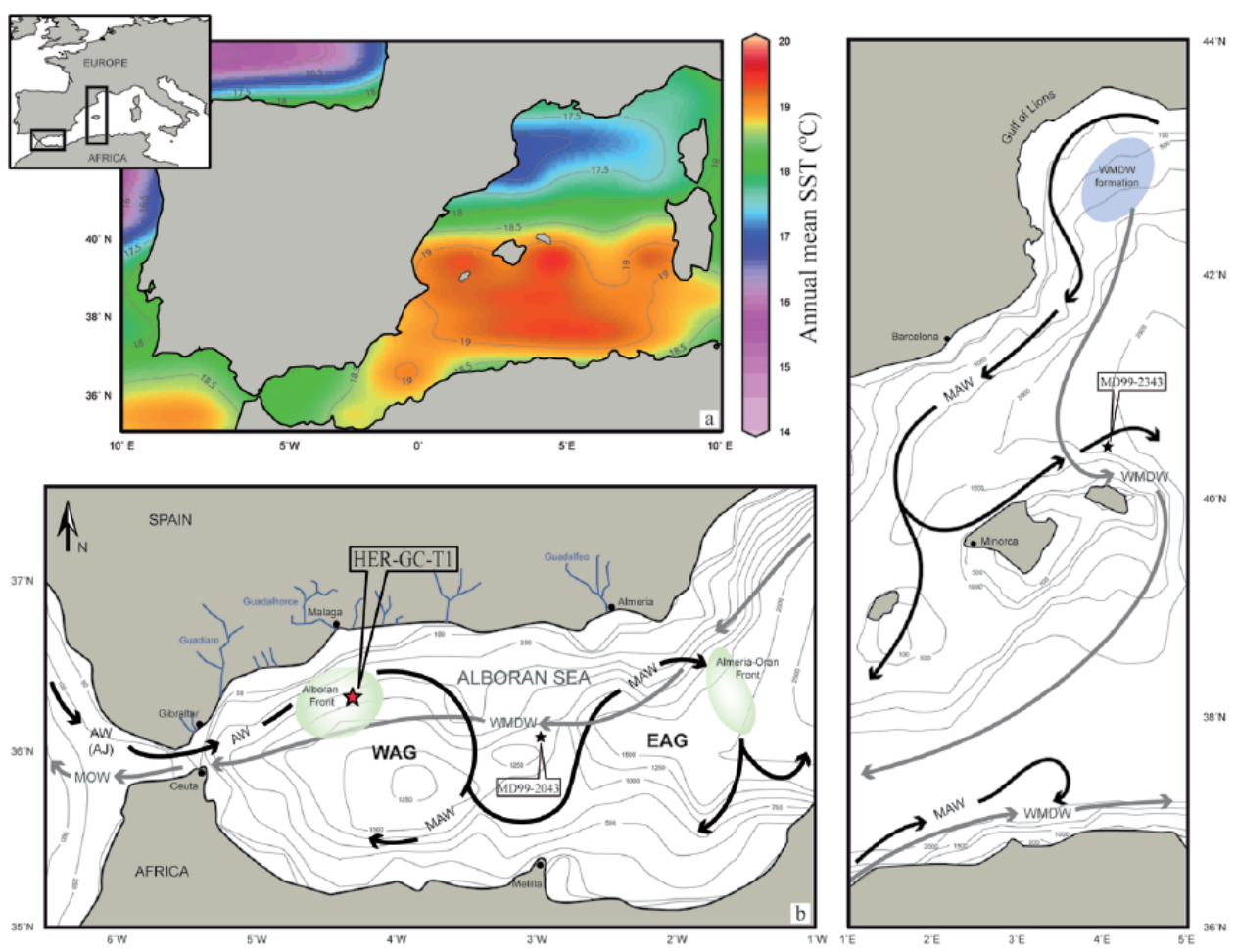

Figure I. Study area: (a) map of the annual mean SST $\left({ }^{\circ} \mathrm{C}\right)$ in the Western Mediterranean Sea plotted with Ocean Data View (Brown, 1998), (b) study area and HER-GC-TI core location in the Alboran Sea and (c) Gulf of Lions area where WMDW formation occurs. Black arrows represent general superficial circulation. Grey arrows trace general deep circulation.

2003). Upwelling dynamics are steered by local hydrography and atmospheric circulation (García-Gorriz and Carr, 1999). The pattern is as follows: offshore upwelling associated with southward drifting of the Atlantic Jet (AJ) and wind-induced coastal upwelling on the shore, promoted by winds blowing along the Spanish coast (Sarhan et al., 2000). The semi-enclosed features of the Alboran Sea lead to partial isolation of these phenomena, making it an ideal region for the study of the impact of short-term climatic oscillations on ocean productivity. Its latitudinal position and its connection with the Atlantic Ocean also provide a reasonable area for the study of ocean-climate teleconnections between northern processes and lower latitudes.

Coccolithophores are haptophyte algae with calcified scales (coccoliths). Living forms are one of the major oceanic primary producers, and they are strongly influenced by nutrient availability, dissolved $\mathrm{CO}_{2}$ concentrations in sea water and sea-surface temperature (SST), among others (Thierstein and Young, 2004). Thus, fossil forms of coccoliths preserved in deep-sea sediments are commonly used as a widespread proxy to reconstruct some of these variables as well as productivity (Baumann and Freitag, 2004; ColmeneroHidalgo et al., 2004; Flores et al., 1999, 2000; Giraudeau, 1992).

The main objective of this study was to reconstruct past productivity in an upwelling area of the Alboran Sea during the Holocene and to elucidate the climatic and oceanographic mechanisms involved in past variations in productivity, especially those related to North Atlantic climatic and oceanographic dynamics. For this reason, we report here a marine productivity record reconstructed from fossil coccolithophores along with data on oxygen isotopes, alkenone-estimated SST and other organic biomarkers for the last $12 \mathrm{ka}$ and correlate them with data referring to paleoenvironmental variations.

\section{Area of study: Modern water masses and climatic dynamics}

Core HER-GC-T1 was recovered off the coast of Malaga (Figure 1b) in the Alboran Sea (Western Mediterranean). This is a transitional region where Atlantic Water (AW) enters the Mediterranean Sea through the Strait of Gibraltar as a jet of water called the AJ (García Lafuente et al., 2000) and becomes two quasi-permanent anti-cyclonic gyres on its way to the east: the western anti-cyclonic gyre (WAG) and the eastern one (EAG; Heburn and La Violette, 1990). The interaction between AW and the more saline and warmer Mediterranean water (MW) results in the formation of a geostrophic front at the northern limit of the WAG, called the Alboran Front (where HER-GC-T1 is located; Minas et al., 1991; Figure 1b). Southward migrations of the AJ allow the water from below, relatively warm and fresh, to upwell in the study area (Sarhan et al., 2000) forming a high-productivity cell referred to here as the 'Malaga cell'.

At depth, water circulation may be simplified with a threelayer model: on the surface, the mixing of AW and MW forms the modified Atlantic Water (MAW), occupying the photic zone (100-200m). Below, Levantine Intermediate Water (LIW), formed in the eastern part of the Mediterranean Sea, flows at a depth of $200-600 \mathrm{~m}$ towards the Strait of Gibraltar. Below the LIW, Western Mediterranean Deep Water (WMDW) flows at $600-3000 \mathrm{~m}$ depth in the same direction (Millot, 1999). WMDW is formed in the open sea off the Gulf of Lions (Figure 1c; MEDOCGROUP, 1970). This deep water convection has a thermohaline origin and is linked to buoyancy preconditions determined by the heat flux, which in turn is steered by the blowing winds: the Tramontana (northerlies) and/or Mistral (north-westerlies; Font et al., 2007; Mertens and Schott, 1998; Rixen et al., 2005; Smith et al., 2008). These cold dry winds blowing over the area induce heat losses and the evaporation of the MAW, which becomes saltier and colder and finally sinks owing to its high density, to form the WMDW (Font et al., 2007)

Present climate conditions in the region are influenced by an atmospheric high-pressure centre above the Azores archipelago in the Atlantic Ocean resulting in hot dry summers and wetter winters (Sumner et al., 2001). At decadal and inter-annual time scales, climatic variability in the North Atlantic region is modulated by the NAO (Hurrell, 1995). Currently, winter anomalies of the NAO in 
Table I. Age model for core HER-GC-TI.

\begin{tabular}{|c|c|c|c|c|}
\hline $\begin{array}{l}\text { Radiocarbon (sample/ } \\
\text { laboratory code) }\end{array}$ & Foram type & Depth $(\mathrm{cm})$ & Radiocarbon age (yr BP) & $\begin{array}{l}\text { Calendar age (2-sigma } \\
\text { error range) (yr cal. BP) }\end{array}$ \\
\hline SECI_2/Poz-53233a & G. inflata & 2 & $440 \pm 25$ & $88 \pm 62$ \\
\hline SECI_2I/OS-87586b & G. inflata & 21 & $1810 \pm 25$ & $1379 \pm 54$ \\
\hline SECI_63/Poz-53234a & G. inflata & 63 & $4175 \pm 35$ & $4284 \pm 76$ \\
\hline SEC2_I7/Poz-53235a & G. inflata & 107 & $6100 \pm 40$ & $6550 \pm 68$ \\
\hline SEC2_54/OS-87587b & G. inflata and N. pachyderma & 144 & $7350 \pm 35$ & $7834 \pm 58$ \\
\hline SEC3_I2/Poz-53236a & N. pachyderma & 202 & $10,400 \pm 60$ & $11,539 \pm 162$ \\
\hline
\end{tabular}

aPoznan Radiocarbon Laboratory.

bWoods Hole Oceanographic Institution.

the Mediterranean have been shown to influence sea-level variability (Tsimplis and Josey, 2001), wave climate (Cañellas et al., 2010) and temperature and precipitation trends to a significant extent (Lionello et al., 2006). The NAO has been suggested to exert an indirect influence on net water flux in the Strait of Gibraltar via its high correlation with regional evaporation, precipitation and runoff (Fenoglio-Marc et al., 2013). The winter-NAO has also been correlated with heat flux anomalies that determine the buoyancy preconditions of deep water convection in the Gulf of Lions (Rixen et al., 2005), although Josey et al. (2011), using a broader definition of winter (October-March), concluded that the NAO only plays a secondary role when other modes of variability related to the heat flux are considered.

\section{Material and methods}

We analysed the top $183 \mathrm{~cm}$ of gravity core HER-GC-T1 (latitude: $36^{\circ} 22^{\prime} 12^{\prime \prime} \mathrm{N}$, longitude: $\left.4^{\circ} 17^{\prime} 57^{\prime \prime} \mathrm{W}\right)$, recovered by the BIO Hesperides during the Hermesione research cruise in 2009, from a depth of 658.9 m.b.s.l. The sediments recovered are mainly composed of dark greenish-grey mud rich in planktonic foraminifers.

\section{Age model}

Radiocarbon ages were determined on six samples of selected foraminiferal shells using the accelerator mass spectrometry (AMS) technique (Table 1) at the Poznan Radiocarbon Laboratory and Woods Hole Oceanographic Institution. Conversion from radiocarbon ages to calibrated calendar years was performed using the OxCal 4.2 online software (Bronk Ramsey, 2008) and the Marine13 calibration data set curve (Reimer et al., 2013), which includes a correction of 400 years for the global marine reservoir effect. The regional difference from this global reservoir correction $(\Delta R$; Stuiver and Braziunas, 1993) proved to be $-22 \pm 35$ years (Siani et al., 2000) and was also considered. The age model for the last $12 \mathrm{ka}$ was based on linear interpolation between these six calendar ages (Figure 2) performed with the AnalySeries Version 1.1 (Paillard et al., 1996). The average sedimentation rate was found to be $18.41 \pm 5.4 \mathrm{~cm} \mathrm{ka}^{-1}$. All dates reported in the text are given in calendar ages BP.

\section{Coccolithophore analysis and taxonomy}

Eighty-five samples were taken systematically every $2-3 \mathrm{~cm}$. The resulting sampling gives an average time resolution of $\sim 140$ years. Slides for micropaleontological analyses were prepared following the settling technique proposed by Flores and Sierro (1997). Qualitative and quantitative analyses were performed using a Nikon Eclipse 80-i petrographic microscope with a phase contrast device at $1000 \times$ magnification. Nannofossil census counts were based on at least 500 specimens identified in a first count, which is representative for studying the main species (Fatela and Taborda, 2002). In a second count, 25 fields of view were observed in order to avoid

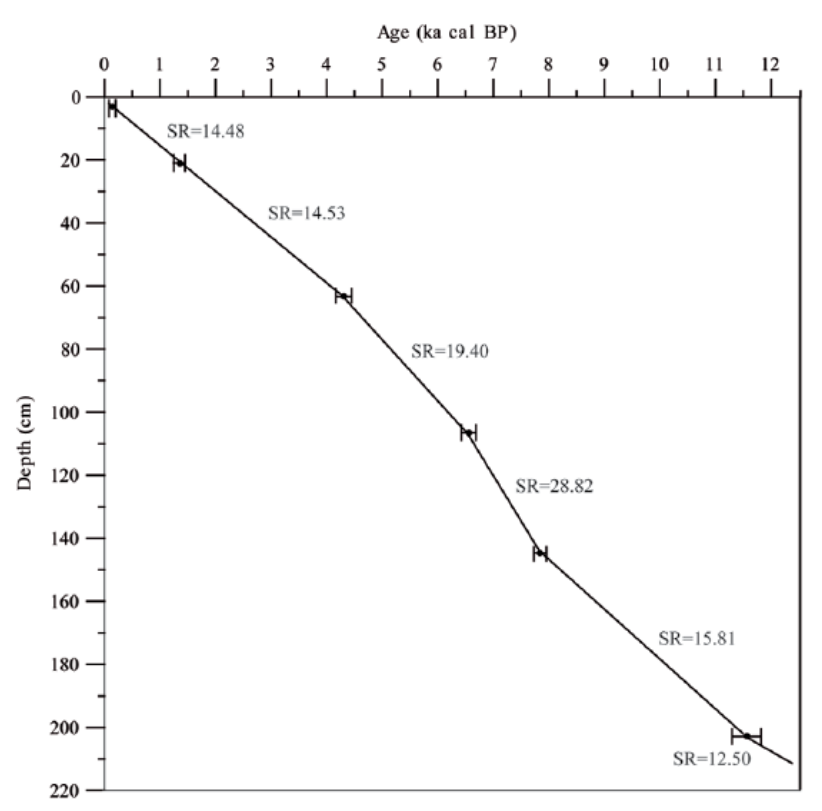

Figure 2. Age-depth model. Age control points are marked by a black dot and associated error bars. The solid line joining them is the age (in ka cal. BP).

SR: sedimentation rate (in $\mathrm{cm} \mathrm{ka}^{-1}$ ).

underestimation and/or overestimation of the taxa whose abundance was less than $1 \%$ in the first count. The nannofossil accumulation rate (NAR) is given in numbers of coccoliths per square centimetre per kiloannum and was calculated in each sample by considering dry-sediment density, the sedimentation rate and the absolute abundance of each species (number of coccoliths per gram). The total NAR was interpreted as a proxy of primary productivity. Relative abundance (\%) was also calculated. All taxa identified in this study have been reported previously for the sampling location (Álvarez et al., 2010; Weaver and Pujol, 1988). The 'small Gephyrocapsa' group is integrated by all Gephyrocapsa specimens smaller than $3 \mu \mathrm{m}$ (Flores et al., 1999). Along with Emiliania huxleyi $(<4 \mu \mathrm{m})$, they were lumped together as 'small placoliths'. Other taxa identified in this study were Gephyrocapsa muellerae, Gephyrocapsa oceanica, Helicosphaera carteri, Syracosphaera spp. and Florisphaera profunda (as dominant taxa). The rare taxa identified were Braarudosphaera bigelowii, Calcidiscus leptoporus, Calciosolenia murrayi, Coccolithus pelagicus subsp. braarudii, Coccolithus pelagicus subsp. pelagicus, Gephyrocapsa caribbeanica, Oolithotus fragilis, Pontosphaera spp., Rhabdosphaera clavigera, Umbilicosphaera sibogae, Umbellosphaera spp. and Discosphaera tubifera. The latter four were lumped together as the warm water group (WWG) owing to their common and relatively high record in warm waters (McIntyre and Bé, 1967; Okada and Honjo, 1973). Taxa pertaining to older stratigraphic levels (regularly older than the Pliocene in this study) were 
deposited again after their resuspension and transport to the core location and were also counted as rare species and designated 'reworked specimens'.

The preservation of the coccolithophore assemblages is good (little or no evidence of dissolution; diagnostic features fully preserved; Flores and Marino, 2002). Moreover, the NARs were transformed into coccoliths per square metre per day. The results are comparable to the annual flux found by Bárcena et al. (2004) in the same area for sediment-trap samples, showing that dissolution and taphonomic effects are negligible in this core.

\section{Oxygen stable isotopes}

Up to 20 well-preserved specimens of the planktic foraminifer Globigerina bulloides were picked from the $>200 \mu \mathrm{m}$ size fraction in 66 samples. The individuals were crushed, subjected to ultrasound and cleaned with methanol before isotopic analyses were performed with a SIRA mass spectrometer equipped with a VG Isocarb common acid bath system at the University of Barcelona. Calibration to the Vienna Pee Dee Belemnite (VPDB) standard scale (Coplen, 1996) was accomplished using the NBS-19 standard, and analytical precision was better than $0.06 \%$ for $\delta^{18} \mathrm{O}$.

\section{Molecular biomarkers}

A total of 86 samples, taken every $2-3 \mathrm{~cm}$, were selected for the analysis of fossil organic compounds (long chain alkenones, alcohols and hydrocarbons). The experimental procedures used are described in Villanueva et al. (1997). Samples were analysed with a varian gas chromatograph (GC) model 450, an autoSampler 8400, a cold on-column (COC) injector 1093 and a flame ionisation detector (FID). The carrier gas was hydrogen $\left(2.5 \mathrm{~mL} \mathrm{~min}^{-1}\right)$. $\mathrm{C}_{37}$ unsaturated alkenones (di-unsaturated and tri-unsaturated) are synthesised by coccolithophorid flora. Their identification and quantification allow the calculation of the $\mathrm{U}_{37}^{\mathrm{k}^{\prime}}$ index, which was calibrated according to the equation proposed by Müller et al. (1998) in order to measure SST. The total concentration of $\mathrm{C}_{37}$ alkenones $\left(\left[\mathrm{C}_{37: 2}+\mathrm{C}_{37: 3}\right]\right)$ was also calculated and is interpreted as a proxy for poor or good preservation of organic matter in deep sea sediments in relation to well or poorly ventilated deep waters (Cacho et al., 2002). The $n$-hexacosan-1-ol index was calculated through the relative ratio of $n$-hexacosan-1-ol $\left(\mathrm{C}_{26} \mathrm{OH}\right)$ to the sum of $\left(\mathrm{C}_{26} \mathrm{OH}\right)$ plus $n$-nonacosane $\left(\mathrm{C}_{29}\right)$. Since $n$-hexacosanol is more labile to degradation processes than $n$-nonacosane, decreases in the $n$-hexacosan-1-ol index can be interpreted as a higher ventilation of the deep basin (Cacho et al., 2000).

\section{Statistical approaches}

In order to search for possible relationships between some of the proxies addressed here, statistical cross-correlation, which is suitable for temporal series, was carried out using PAST 3.01 software (Hammer et al., 2001). This method requires evenly sampled temporal data, which were interpolated regularly every $0.14 \mathrm{ka}$ (the lowest resolution among those from all of the records correlated).

\section{Results}

\section{Calcareous nannoflora distribution}

On average, small placoliths constitute up to $80 \%$ of the nannofossil assemblage (Figure 3). Their NAR records maximum values from 7.7 to $6.2 \mathrm{ka}$. G. muellerae (Figure 3 ) is the only species that records its highest NAR from 12 to $10.5 \mathrm{ka}$, followed by a decreasing trend from $10.5 \mathrm{ka}$ onwards, interrupted only by higher values from 7.7 to $6.2 \mathrm{ka}$. The NAR of the WWG is scarce for the whole period studied, except from 7.7 to $6.4 \mathrm{ka}$ when it records higher values (Figure 3). F. profunda and small G. oceanica exhibit similar general variability (Figure 3): a low NAR up to $7.7 \mathrm{ka}$, when a large peak is observed; from then onwards up-core, they record higher NAR values as well as large oscillations.

Reworked specimens are mainly constituted by Upper Cretaceous, Paleogene and Neogene specimens. On average, the percent of this allochthonous group relative to autochthonous taxa (Figure 3) is $0.7 \%$ for the whole record. However, it shows five peaks up to $1.6 \%$ at $7.0,6.2,5.0,4.1$ and $2.8 \mathrm{ka}$.

The total NAR (Figure 3 ) shows an increasing trend from 12.5 to $7.7 \mathrm{ka}$. From that time onwards up to $6.5 \mathrm{ka}$, it records its highest values followed by a decreasing trend up-core.

\section{SST}

$\mathrm{U}_{37}^{\mathrm{k}^{\prime}}$-estimated SST (Figure 3 ) has its absolute minimum $\left(14.6^{\circ} \mathrm{C}\right)$ at $12 \mathrm{ka}$, and its absolute maximum $\left(20.1^{\circ} \mathrm{C}\right)$ at $8.9 \mathrm{ka}$. A decreasing trend is observed from $8.9 \mathrm{ka}$ up-core, characterised by a generalised smooth internal variability. More specifically, short cooling events (up to $1^{\circ} \mathrm{C}$ ) are seen centred at 11.5, 10.4, 8.5, 7.7, 5.3 and $0.8 \mathrm{ka}$.

\section{Oxygen isotopic record}

As from $12 \mathrm{ka}$ (Figure 4c), this record tends to lower values, its absolute minimum being reached at $7.8 \mathrm{ka}$ and its values varying up to $1.48 \%$ during that period. From 7.8 to $3.8 \mathrm{ka}$, several slight depletions interrupt a trend to higher values, increasing by a total of $0.98 \%$. From $3.8 \mathrm{ka}$ to the top, $\delta^{18} \mathrm{O}$ tends towards slightly lower values, with a range of $0.43 \%$.

\section{Total concentration of $C_{37}$ alkenones and the n-hexacosan-l-ol index}

The total concentration of $\mathrm{C}_{37}$ alkenones (Figure $4 \mathrm{~d}$ ) shows higher values from 12 to $9 \mathrm{ka}$. This record is affected by a decreasing trend up to $7.5 \mathrm{ka}$, and from that time onwards up-core, it shows low values and little variability. The $n$-hexacosan-1-ol index (Figure $4 \mathrm{e}$ ) tends towards lower values from 12 to $7.5 \mathrm{ka}$. After the absolute minimum recorded at $7.5 \mathrm{ka}$, a trend towards higher values is recorded up-core, punctuated by several depletions.

\section{Discussion}

\section{General primary productivity and SST trends}

Holocene productivity can be divided into three periods according to the total NAR variability (Figure 3): from 25.5 to $7.7 \mathrm{ka}$, characterised by low productivity and a slight increasing trend; from 7.7 to $6.2 \mathrm{ka}$, when productivity reached its highest values; and from $6.2 \mathrm{ka}$ onwards, a period affected by lower productivity and a slight decreasing trend up-core.

Specifically from 12 to $10.5 \mathrm{ka}$, low SST values correspond to a high $G$. muellerae NAR and relative abundances and a low WWG NAR and relative abundances (Figure 3), customarily used as cold water and warm water proxies, respectively (McIntyre and Bé, 1967; Okada and Honjo, 1973; Weaver and Pujol, 1988).

The long-term cooling trend shown by the $\mathrm{U}_{37}^{\mathrm{k}^{\prime}}$-estimated SSTs from $9 \mathrm{ka}$ during the Holocene is in agreement with the findings of Marchal et al. (2002) from the study of seven cores from the north-east Atlantic and the Mediterranean Sea. However, from 7.7 to $6.2 \mathrm{ka}$, there is no agreement between the total NAR and the SST cooling trend, suggesting that factors other than SST would have controlled coccolithophore production and variability during that time. Specifically, the signal of WWG (Figure 3) results from the sum of all taxa with a preference for warm waters. This does not exclude the possibility that other environmental parameters such us salinity, nutrients, eddies and 


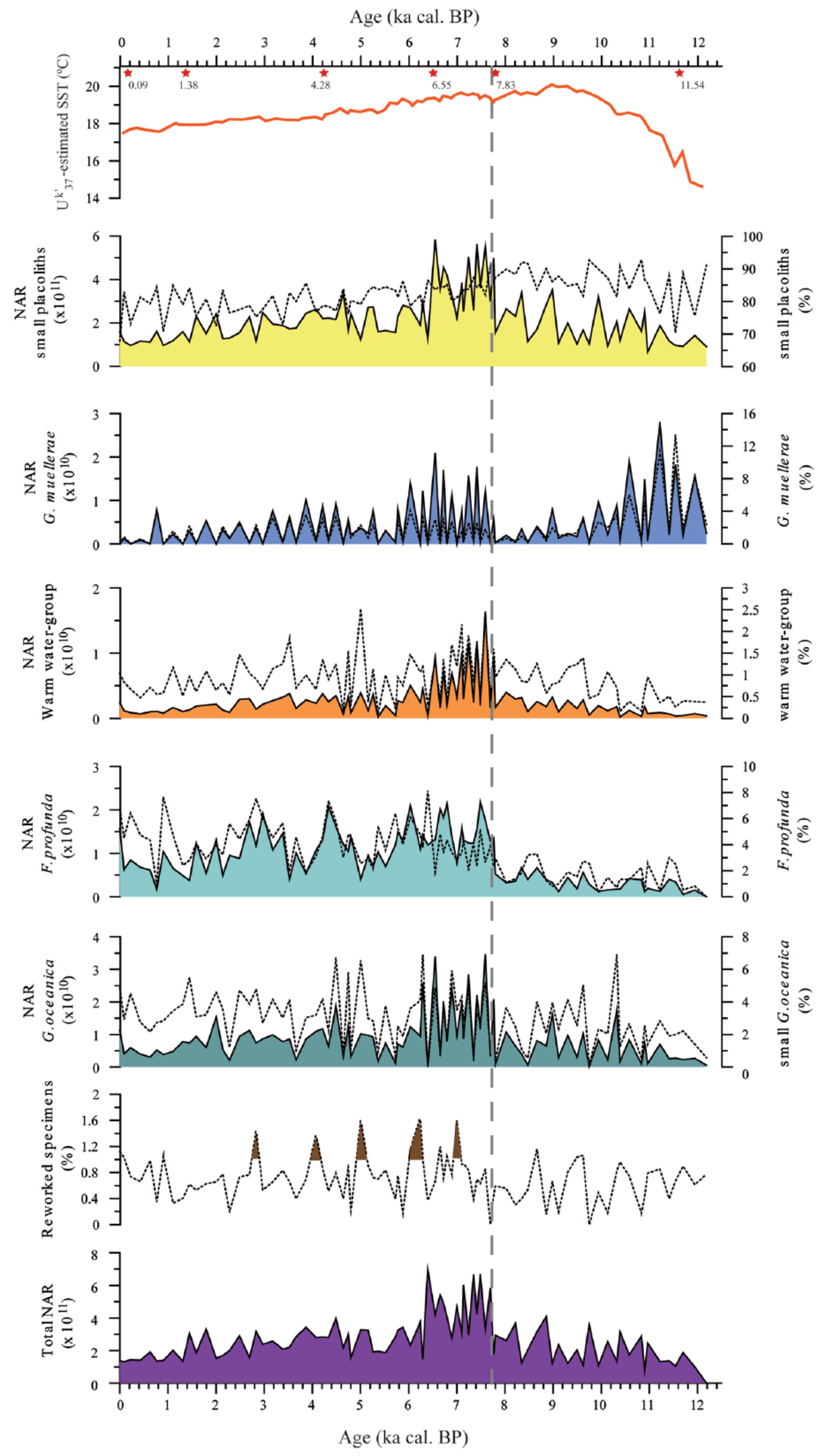

Figure 3. $U_{37}^{k^{\prime}}$-estimated SST $\left({ }^{\circ} \mathrm{C}\right)$. Nannofossil accumulation rate (NAR; black lines) and relative abundance (\%; dashed line) of the coccolithophore assemblage. The grey dashed vertical line indicates the $7.7 \mathrm{ka}$ cal. BP event. Red stars represent age control points (ka cal. BP; Table I). 


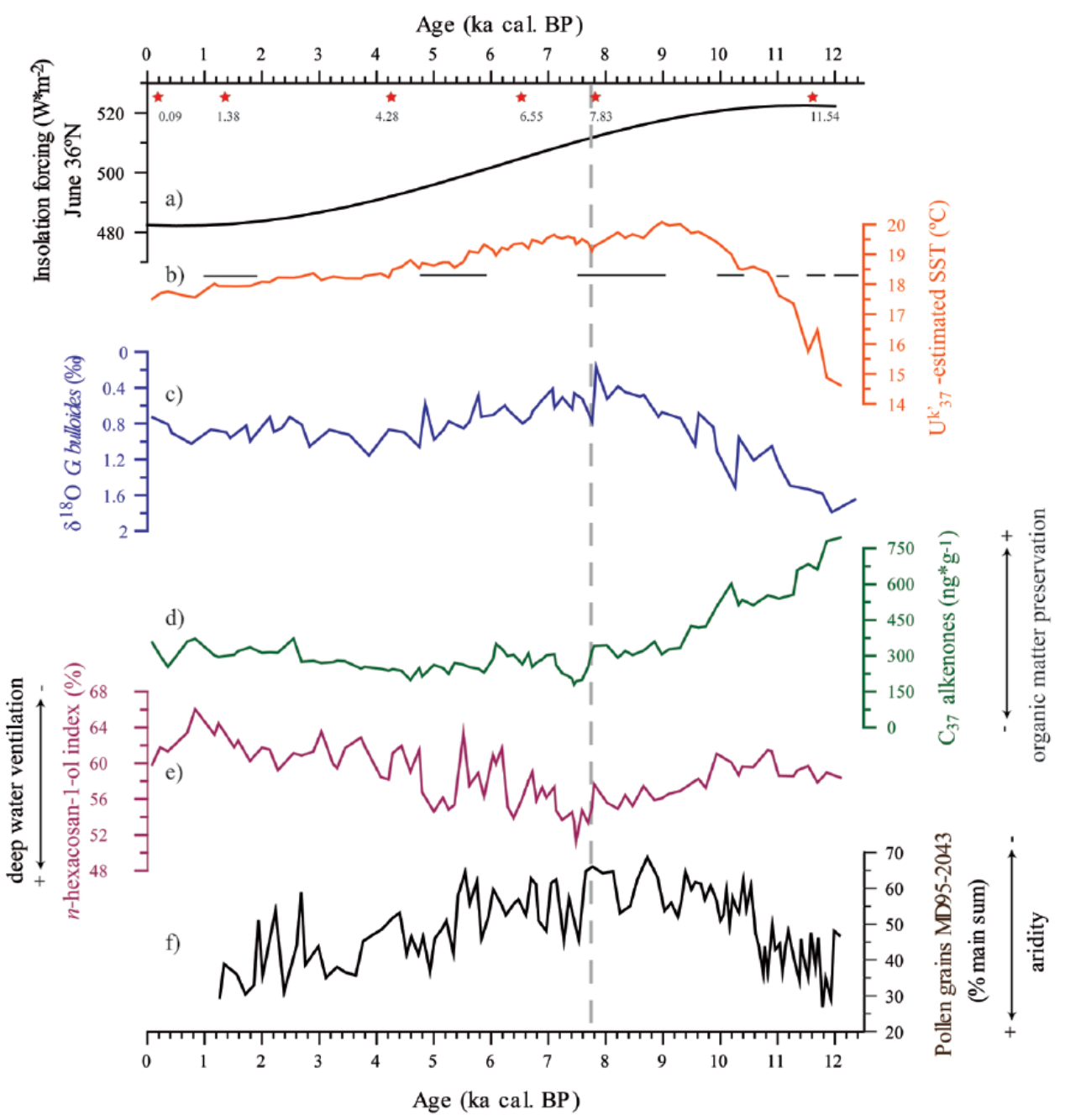

Figure 4. (a) Insolation curve (June, $36^{\circ} \mathrm{N}$; Berger, 1978). (b) $\bigcup_{37}^{k^{\prime}}$-estimated SST ( ${ }^{\circ} \mathrm{C}$ ). Horizontal lines mark the rapid Holocene cooling events identified by Cacho et al. (200I). (c) $\delta^{18} \mathrm{O}$ record (\%o; note that the vertical axis is reversed). (d) Concentration of $\mathrm{C}_{37}$ alkenones $\left(\left[\mathrm{C}_{37: 2}+\mathrm{C}_{37.3}\right] ; \mathrm{ngg}^{-1}\right)$. (e) $n$-hexacosan-I-ol index (\%). (f) Pollen grains from core MD95-2043 in the Alboran Sea for all temperatures and Mediterranean forest taxa (Fletcher et al., 2012).

SST: sea-surface temperature.

species-specific biogeography could affect their distribution and variability (Baumann et al., 2005) and hence their signal in paleorecords.

Despite this general cooling trend, the G. muellerae NAR and relative abundances decrease from $6.2 \mathrm{ka}$ up-core, showing similar variability to that of the small placoliths, which are eurythermal species linked to the presence of nutrients (Okada and Wells, 1997). Both taxa could have been controlled by the same factors since they show similar responses. Flores et al. (1997) found low abundances of G. muellerae after the early part of the last Pleniglacial $(73.9 \mathrm{ka})$ in the Western Mediterranean, suggesting that the affinity of this species for cold water conditions is unclear. We suggest that the abundance of G. muellerae has been responding not only to colder waters but also to nutrient availability as from $7.7 \mathrm{ka}$.

The NAR and relative abundances of F. profunda (Figure 3) increase at $7.7 \mathrm{ka}$ and undergo several high-amplitude oscillations up-core as from that time. This species inhabits the lower photic zone (LPZ) and is abundant under a deep nutricline and an upper photic zone (UPZ) impoverished in nutrients (Molfino and McIntyre, 1990), a characteristic that affected the water column in the Alboran Sea during several periods of the last $7.7 \mathrm{ka}$.

The general trends shown by the SST profile are similar to that shown by the $\delta^{18} \mathrm{O}$ record (Figure 4 ). From $8.9 \mathrm{ka}$, both profiles follow a decreasing trend in agreement with that of the insolation curve (Figure 4a; Berger, 1978). This suggests that insolation could have played an important role from that time onwards along the Holocene as a long-term factor influencing the SST, which in turn would have had an important effect on the isotopic composition of oxygen recorded in foraminiferal shells.

With regard to deep basin conditions, a period of well-preserved organic matter from 12 to $9.5 \mathrm{ka}$ can be deduced from the higher concentration of $\mathrm{C}_{37}$ alkenones (Figure $4 \mathrm{~d}$ ). This period coincides with the last part of the organic-rich layer (ORL-1) reported by Cacho et al. (2002) in the Alboran Sea due to an oxygen-depleted environment during the deglaciation. The preservation of organic matter declines until $7.5 \mathrm{ka}$, coherent with the gradual increase in deep water ventilation shown by the $n$-hexacosan-1-ol index (Figure 4e). From these conditions, we deduce a period of thermohaline reactivation that gradually decreases from $7.5 \mathrm{ka}$ onwards. During this latter period, the preservation of the organic matter is relatively low, although a slight increasing trend up-core can be recognised in the total concentration of $\mathrm{C}_{37}$ alkenones, in agreement with the gradual reduction in deep water ventilation (Figure 4e), while, according to the total NAR, lower productivity affects the photic zone (Figure 3).

According to Fletcher et al. (2012), continental aridity is evidenced by pollen analysis of the marine core MD95-2043 (Figures $1 \mathrm{~b}$ and $4 \mathrm{f}$ ). This record shows a decreasing abundance of Mediterranean and temperate pollen grains up-core, pointing to a gradual decline in forest mass and more arid conditions during the Holocene. 


\section{Short-term changes}

The 7.7-ka event. At $7.7 \mathrm{ka}$, there is a simultaneous increase in the NAR of all dominant taxa (Figure 3 ). The high sedimentation rate from 7.7 to $6.2 \mathrm{ka}$ (Figure 2) is partly responsible for this increase in NARs, since these depend on the former for its calculation. Nevertheless, the absolute abundances (coccoliths $\mathrm{g}^{-1}$ ) of these taxa also reflect this sharp increase at that time (data not shown), from which it may be deduced that the simultaneous increase in the NAR at $7.7 \mathrm{ka}$ is not an artefact of the sedimentation rate. In addition, F. profunda NAR shows several high-amplitude oscillations from $7.7 \mathrm{ka}$, pointing to successive periods of high productivity in the LPZ, and therefore, a change in the configuration of the upper water column may be deduced from then onwards up-core. Because all taxa were affected, even though some of them have different and/or opposite ecological preferences (e.g. nutrient availability and SST), we argue that the same ecological factors (or at least one) controlled them. We propose an increase in the Atlantic inflow in the Western Mediterranean Sea, as shown by the maximum flooding of the Southern coast of Spain dated at 7.4 ka (Zazo et al., 1994), and the ensuing establishment of the WAG in the Alboran basin as a possible cause for this simultaneous peak in all NAR profiles. Directly associated with the appearance of the WAG, the productive 'Malaga cell' would have been settled at that time, implying a nutrient input that would favour the blooming of all species.

It is worth noting that at $7.5 \mathrm{ka}$, the $n$-hexacosan-1-ol index records its absolute minimum coeval with low values of the total concentration of $\mathrm{C}_{37}$ alkenones (Figure $4 \mathrm{~d}$ and e), pointing to a well-ventilated deep basin. In this regard, Naranjo et al. (2012) demonstrated that the intensification of the WAG is able to ventilate deep waters in the Alboran Sea. Rohling et al. (1995) reported the establishment of the WAG at around $8 \mathrm{ka}$ from the interpretation of an abrupt faunal change in the planktic foraminiferal assemblage, also identified and dated by Pérez-Folgado et al. (2003) at $7.7 \mathrm{ka}$. A change in the benthic foraminiferal assemblage was also recognised by Melki et al. (2009) at $8 \mathrm{ka}$ in the Gulf of Lions. Jimenez-Espejo et al. (2007) deduced a remarkable redox event in the Algero-Balearic basin between 7.5 and $7 \mathrm{ka}$, interpreted as the redoxcline reaching the seabed due to intensification of the thermohaline circulation. From the analyses of pollen records, Fletcher et al. (2012) reported a long-term decline in Mediterranean forest levels from $7.5 \mathrm{ka}$. Reviewing many paleoenvironmental records from marine and continental sites in the study area, Cortés Sánchez et al. (2012) deduced a long-term environmental crisis due to sea-level rise and changes in the thermohaline circulation at that time. Based on our results, we suggest that the 7.7-ka event observed in the NAR records would correspond to the appearance of the 'Malaga cell' as a consequence of the establishment of the WAG. Ultimately, this would have been due to a major inflowing AJ along with an intensification of the thermohaline circulation in the Western Mediterranean at that time.

Variability of the productive 'Malaga cell'. The F. profunda NAR and relative abundances show large oscillations from the proposed appearance of the 'Malaga cell' onwards. The relative abundance of this species has classically been used as a nutricline depth indicator in paleoceanographic reconstructions in low latitudes, where $F$. profunda shows high relative abundances and may have dominated the assemblages during some periods (Beaufort et al., 1997; Flores et al., 2000; Incarbona et al., 2008; Molfino and McIntyre, 1990). In our records, F. profunda ranges up to $8 \%$ of the total assemblage and its average contribution $(3.3 \%)$ is low, in agreement with sediment-trap analyses from the Alboran Sea (4\% and 2.5\%; Bárcena et al., 2004; Hernández-Almeida et al., 2011). Regarding relative abundances, the decrease or increase of one species may occur when other species increase or decrease, even though the absolute value of the former does not change. Because the changes in the relative abundance of F. profunda are of small magnitude, we interpret the NAR as a more suitable expression of $F$. profunda abundance and variability in this study. This species requires nutrients available in the LPZ (deeper nutricline) and low turbidity (lower productivity in the UPZ; Ahagon et al., 1993) to allow light to reach the LPZ, and hence, high values of $F$. profunda NAR can be suggested to represent these conditions. This argument is supported by the study of sediment-trap samples in the Alboran Sea, where the highest fluxes of $F$. profunda have been reported along with water column stratification (HernándezAlmeida et al., 2011). Similarly, in a recent study carried out in Bay of Bengal, Mergulhao et al. (2013) linked high fluxes of $F$. profunda to a deep nutricline when oligotrophic conditions prevailed at the surface.

Conversely, the decreases in the $F$. profunda NAR were likely due to a shallower nutricline and/or higher turbulence in the UPZ, characteristic conditions of upwelling intensification. Small placoliths are a classic indicator of rich-nutrient waters in the UPZ (Okada and Wells, 1997). However, they show scarce variability from $7.7 \mathrm{ka}$ onwards and, as is the case of the relative abundance of $F$. profunda, changes of small magnitude (Figure 3), and hence, it is not possible to deduce periods of higher productivity from their record. Nevertheless, we argue that decreases in the $F$. profunda NAR would have been linked to the intensification of the upwelling conditions, as demonstrated by Ziveri et al. (1995) from the study of sediment-trap samples, where the lowest fluxes of $F$. profunda were linked to a shoaling of the nutricline during the upwelling period in southern California.

From this, we deduce that the high variability shown by $F$. profunda NAR points to pulses of weakening and intensification of upwelling conditions in the study area, implying that the semipermanent nature of the productive 'Malaga cell' has characterised it for the last $7.7 \mathrm{ka}$.

Upwelling intensity in the study area is linked to AJ dynamics (Sarhan et al., 2000). This implies that more factors would have influenced productivity, since these dynamics in turn are steered by the water exchange controlled hydraulically in the Strait of Gibraltar (García Lafuente et al., 2002). This water exchange determines a net water inflow at the Strait that compensates the freshwater loss at the sea surface induced by evaporation in the Mediterranean Sea (Fenoglio-Marc et al., 2013). With regard to outflow, this is essentially formed by the LIW and WMDW. The latter occupies the bottom layer, and from the study of CTD profiles, the core location has been reported to have been under its direct influence (Ercilla, 2013, personal communication). Frigola et al. (2007) analysed the UP10 fraction (fraction coarser than $10 \mu \mathrm{m}$; Figure 5a) from marine core MD99-2343 (Figure 1c) and interpreted the occurrence of episodes of WMDW reinforcement in the Gulf of Lions for the last $12 \mathrm{ka}$ called the 'Minorca events' (Table 2). There is a general correspondence between periods of maximum UP10 fraction and minimum $F$. profunda NAR, indicating a WMDW reinforcement in the Gulf of Lions coeval with intensification of the upwelling conditions in the Alboran Sea (Table 2, Figure 5). By contrast, during most of the periods in which the UP10 fraction records its lowest values, F. profunda NAR shows large peaks, indicating a relaxation of the upwelling and a more stable water column in the Alboran Sea during periods of WMDW weakening (Figure 5). The cross-correlation between the UP10 fraction and the NAR of $F$. profunda is $R=-0.56, n=85, p$-value $=0.01$ (correlation significant at 99\%). This result highlights the notion that both proxies are anti-correlated at a moderate value. Because Holocene climate records are imperfect proxies for processes containing complicated mixtures of periodic and 


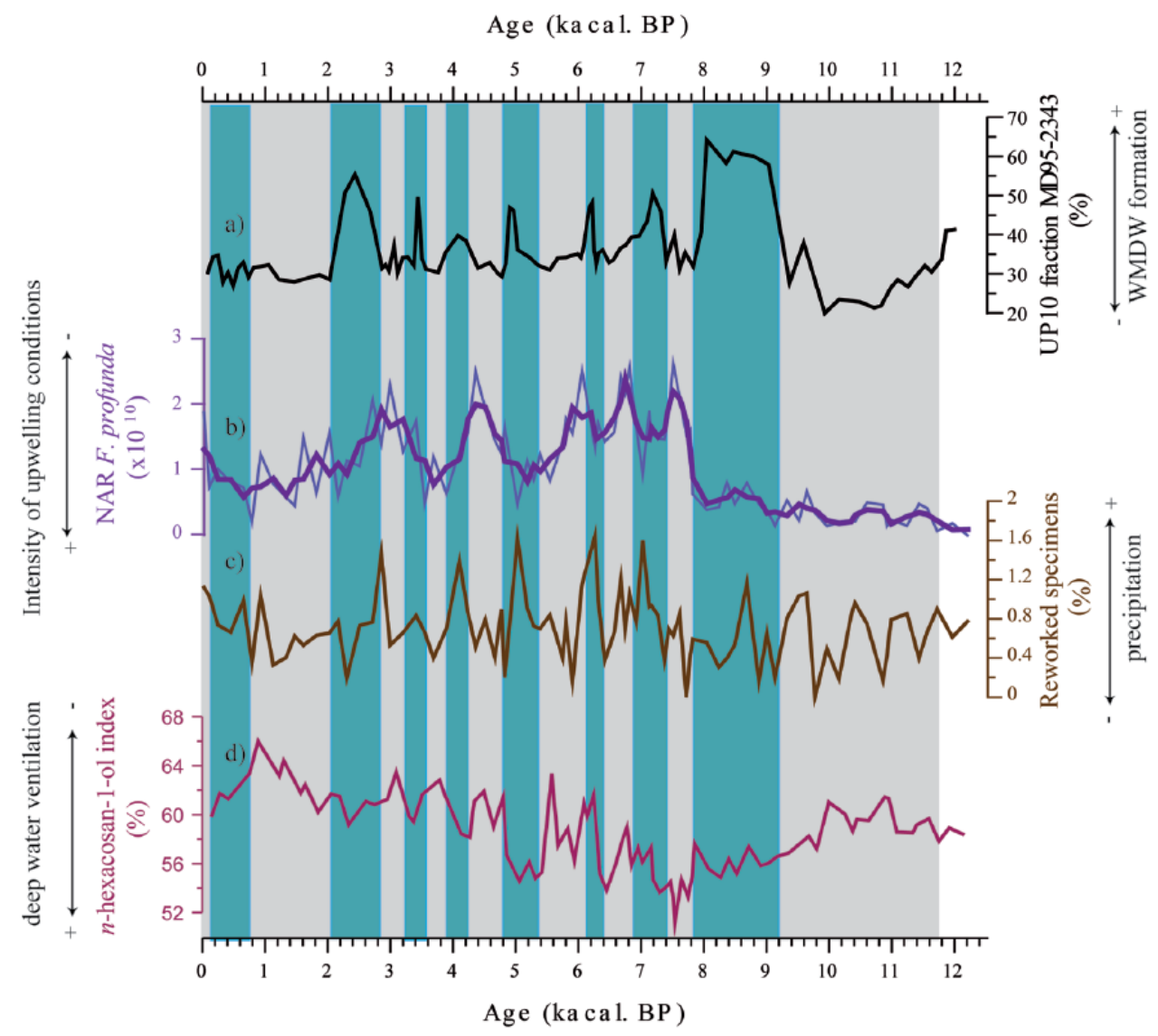

Figure 5. (a) UPIO fraction record from core MD95-2343 north of Minorca (Frigola et al., 2007; \%). (b) F. profunda NAR from core HERGC-TI (coccoliths $\mathrm{cm}^{-2} \mathrm{ka}^{-1}$ ). The thin line represents original values, while the thick line represents the original data fitted to a three-point moving average smoothing spline. (c) Relative abundance of reworked specimens (\%). (d) $n$-hexacosan-I-ol index (\%). Blue bars represent the timing of WMDW reinforcement periods and intensified upwelling conditions in the Alboran Sea. Pale grey bars represent the timing of WMDW weakening periods along with the steadier water column deduced in this study.

Table 2. Timing of Minorca events (WMDW reinforcement) in the Gulf of Lions (Frigola et al., 2007) and timing of the lower values of F. profunda NAR in the Alboran Sea.

\begin{tabular}{|c|c|c|}
\hline \multirow[t]{2}{*}{ Minorca event } & $\begin{array}{l}\text { WMDW reinforcement } \\
\text { periods in Frigola et al. } \\
(2007)\end{array}$ & $\begin{array}{l}\text { F. profunda NAR } \\
\text { decreases in the } \\
\text { Alboran Sea }\end{array}$ \\
\hline & Age interval (ka cal. BP) & $\begin{array}{l}\text { Age interval } \\
\text { (ka cal. BP) }\end{array}$ \\
\hline M8 & $9.0-7.8$ & $9.2-7.8$ \\
\hline M7 & $7.4-6.9$ & $7.4-6.9$ \\
\hline M6 & $6.5-5.8$ & $6.6-6.1$ \\
\hline M5 & $5.3-4.7$ & $5.7-4.7$ \\
\hline M4 & $4.2-4.0$ & $4.2-3.1$ \\
\hline M3 & $3.4-3.1$ & \\
\hline M2 & $2.6-2.3$ & $2.6-2.1$ \\
\hline MI & I.8-I.4 & \\
\hline MO & $0.8-0.2$ & $0.9-0.2$ \\
\hline
\end{tabular}

WMDW:Western Mediterranean Deep Water; NAR: nannofossil accumulation rate.

random signals (Thomson, 1990), complex effects difficult to identify, isolate and remove can affect the correlation parameter. In addition, owing to chronological uncertainties, another significant concern arises when comparing records based on different age models. Thus, it is important to bear in mind that this relatively moderate correlation value results from proxies of different nature (physical and biological), which were measured in different cores from adjacent basins.
According to García Lafuente et al. (2007), the seasonal cycle of the outflow is linked to that of the annual formation of WMDW. García Lafuente et al. (2002) demonstrated that the inflow and outflow fluctuate in-phase. In light of this, it could be suggested that a reinforcement of WMDW would have been simultaneous to an enhanced Atlantic inflow in order to compensate the evaporative losses that promoted WMDW formation. Changes in the AJ velocity forced a change in its incoming direction as follows: higher velocities would have forced the AJ to migrate southward and, as a consequence, upwelling would have occurred offshore since a volume of uplifted waters replaced the space left behind; conversely, lower velocities would have caused the northward displacement of the AJ and the development of the WAG (Cheney and Doblar, 1982; Sarhan et al., 2000; Vargas-Yáñez et al., 2002).

The SST short-term variability shows changes of small amplitude (up to $1^{\circ} \mathrm{C}$ ) that coincide with most of the six short cooling events $\left(1-1.5^{\circ} \mathrm{C}\right)$ recognised by Cacho et al. (2001) in a $\mathrm{U}_{37}^{\mathrm{k}^{\prime}}$ -estimated SST record from the Alboran Sea. Cacho et al. (2001) studied these cooling events along a longitudinal transect and observed that their amplitude was larger eastward. The authors argued that these were transmitted by North Atlantic inflowing but were amplified across the Mediterranean by strong winter winds. Taking into account the location of core HER-GC-T1 in this transect, the smaller magnitude of the SST cooling events is in agreement with the Mediterranean amplification effect reported by Cacho et al. (2001).

At millennial-centennial time scale, SST and $\delta^{18} \mathrm{O}$ variations are not simultaneous. Owing to the oxygen isotope ratios within shells of $G$. bulloides are a function of the local temperature in which the shells forms and the variations in continental ice sheets (Emiliani, 1955), discrepancies between both records may be 


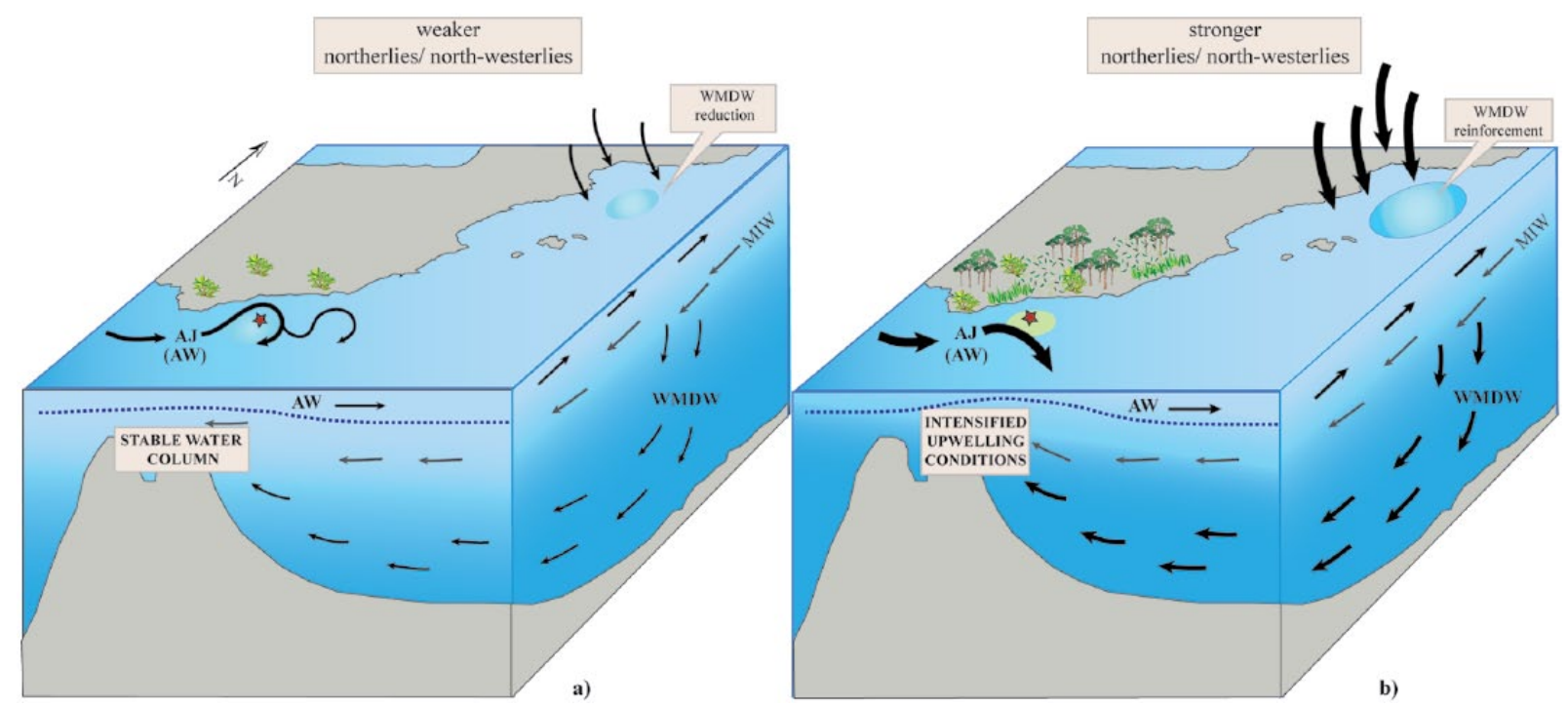

Figure 6. Proposed two-phase scenario: (a) phase I and (b) phase 2 as explained in the text. AW:Atlantic Water; AJ:Atlantic Jet; MIW: Intermediate Water;WMDW:Western Mediterranean Deep Water.

related to surface water salinity changes and/or ecological repercussions from the different planktic groups employed (i.e. the different depths at which G. bulloides calcifies and alkenones are produced).

The five largest peaks shown by the reworked specimens (Figure 5d) may be negligible owing to their low relative abundance (up to $1.6 \%$ ). Nevertheless, we submit that they could have paleosignificance related to the processes described below due to their correspondence with periods of WMDW formation (Figure 5). In the study area, reworked specimens have been linked to terrigenous input from exposed continental margins and fluctuation in the sea level (Colmenero-Hidalgo et al., 2004; Flores et al., 1997). We discard this hypothesis since the estimated changes in relative mean sea levels during the Holocene did not exceed $1.3 \mathrm{~m}$ in the Alboran Sea (Goy et al., 2003). Nevertheless, reworked specimens can be also transported by rivers flowing into the study area (Guadalfeo River and Guadalhorce River (Figure 1b)). Southward migrations of the North Atlantic westerlies (i.e. blowing over the Gulf of Lions) allow the penetration of winter storm tracks in the Mediterranean region. This was observed for the Holocene by Fletcher et al. (2012), who linked southward displacements of the North Atlantic westerlies with forest expansion in the Western Mediterranean. Higher precipitation during times of prevailing westerlies would have involved enhanced fluvial discharges, supporting the transport of reworked specimens by rivers during periods of WMDW formation.

The several changes seen in the $n$-hexacosan-1-ol index (Figure 5c) do not reveal any evident correlation with those of the UP10 fraction. It is expected that after its formation, the WMDW would have ventilated the seafloor on its way to the Strait. However, fluvial discharges in the study area during those periods could have partly masked the short-term ventilation signal shown by the $n$-hexacosan-1-ol index.

From these results, we propose a two-phase scenario to explain the behaviour of the productive Malaga cell at millennial-centennial time scale from its appearance at $7.7 \mathrm{ka}$ : (1) more arid climate conditions and weaker northerlies or north-westerlies in the Gulf of Lions, the latter leading to a reduction in WMDW formation concurrent with a weakening of the AJ inflow. This would have promoted a reduction in vertical mixing (Figure 6a), triggering a weakening of the upwelling conditions and leading to a more stable water column in the Alboran Sea; (2) wetter climate conditions and an intensification of northerly or north-westerly winds in the Gulf of Lions would have prompted a WMDW reinforcement simultaneous with a stronger AJ and its southward migration. This would have caused an increase in vertical mixing, leading to an intensification of the upwelling conditions in the Alboran Sea (Figure 6b).

\section{Proposed forcing mechanism}

Atmospheric pressure over the Mediterranean is the main driving force of water exchange in the Strait (García Lafuente et al., 2002) as well as of the wind intensity, which determines the WMDW formation (Leaman and Schott, 1991; Rixen et al., 2005). On a longer time scale, a NAO-like mode of atmospheric circulation could represent a mechanism influencing climate variability and productivity at a millennial-centennial time scale in the study area due to the well-known climatic teleconnection of the Western Mediterranean with northern latitudes (Cacho et al., 1999; Martrat et al., 2004). This relationship has already been suggested by several authors (Fletcher et al., 2012; Frigola et al., 2007; Goy et al., 2003; Moreno et al., 2004; Sánchez-Goñi et al., 2002), although the interpretations are limited by the absence of a robust paleo-NAO reconstruction. Trouet et al. (2009) reconstructed the winter-NAO circulation pattern for the past 900 years, and later, Olsen et al. (2012) expanded it to 5200 years (Figure 7). A comparison between the winter-NAO reconstruction and the UP10 fraction by Frigola et al. (2007) reveals a good visual match (Figure $7 \mathrm{~b}$ ), supported by the reasonable value of its cross-correlation: $R=0.60, n=45, p$-value $=0.002$.

Trouet et al. (2009) and Olsen et al. (2012) also inferred the NAO index (Figure 7a), which is the normalised December-toMarch sea-level pressure between the Azores high-pressure and the Icelandic low-pressure centres, expressed as a bipolar circulation pattern. Previous work suggests that northerly or westerly winds over the Gulf of Lions as well as enhanced precipitation in the Western Mediterranean would have been triggered during negative NAO-like conditions (Combourieu Nebout et al., 2002; Fletcher et al., 2012; Roberts et al., 2012; Trigo et al., 2004). However, a firm relationship between the timing of periods of intensified upwelling conditions in the Alboran Sea and bimodality in the winter-NAO phases cannot be established from their comparison (Figure 7, dark bars). Nevertheless, we propose the winter-NAO as a likely forcing mechanism directly involved in the intensity of northerly or north-westerly winds that drove WMDW formation, a physical process that here is in turn 


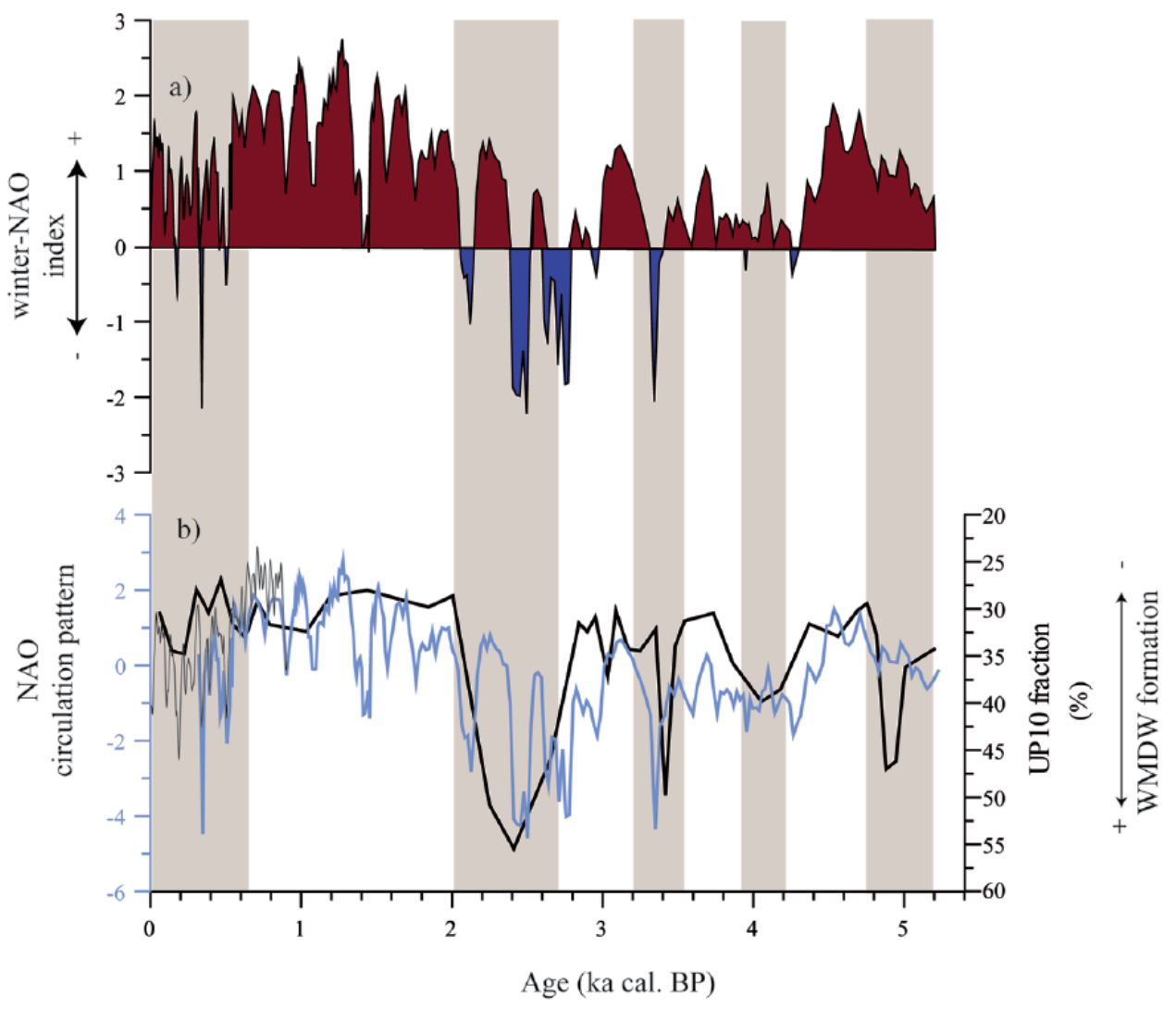

Figure 7. (a) Winter-NAO index (Olsen et al., 20I2; Trouet et al., 2009). Comparison of the winter-NAO circulation pattern according to Trouet et al. (2009), in brown, and to Olsen et al. (2012), in blue, with: (b) the UPIO fraction (reversed vertical axis) from core MD95-2343 (Frigola et al., 2007). Pale brown bars represent the timing of periods of WMDW reinforcement and intensified upwelling conditions in the Alboran Sea.

proposed to be related to the variability of the 'Malaga cell' since its appearance at $7.7 \mathrm{ka}$.

\section{Conclusion}

Down-core variations in the NAR are tightly linked to changes in marine paleoproductivity. A dramatic change observed in the NAR of all coccolithophore taxa at $7.7 \mathrm{ka}$ has been related to a prominent fast-flowing AJ and the ensuing establishment of the WAG. These conditions would have favoured the establishment of the semi-permanent productive 'Malaga cell' at $7.7 \mathrm{ka}$. From that time throughout the Holocene, the area was affected by a general cooling trend, as revealed by alkenone-estimated SST. Nannofossil records point to a general decreasing trend in productivity, altered by higher variability based on the alternation of events of weakened and intensified upwelling conditions since the establishment of the 'Malaga cell'. These variations in productivity have been found to be synchronous with periods of WMDW reinforcement in the Gulf of Lions, in such a way that whenever WMDW formation was strengthened, a productive event would have occurred in the Alboran Sea.

A two-phase scenario (Figure 6) is proposed to describe the main climatic and oceanographic features prevailing in the Western Mediterranean along the Holocene at millennial-centennial time scale: phase 1 together with more arid climate conditions, weaker northerly or north-westerly winds would have resulted in a reduction in WMDW formation in the Gulf of Lions, which would have coincided with a minor AJ influx. As a result, a weakening of the upwelling conditions would occur, and a stable water column would have characterised the study area; phase 2 together with wetter climate conditions, stronger northerlies or north-westerlies blowing over the Gulf of Lions would have driven a major
WMDW formation simultaneous to an enhancement of the AJ influx that would have migrated southward. This would have prompted vertical mixing in the study area intensifying upwelling conditions.

The winter-NAO circulation pattern has proved to be a highly influential mechanism in the processes explained by both phases. These results highlight the sensitivity of the Western Mediterranean to high-latitude climatic systems and point to the 'Malaga cell' as a location of high interest in the Alboran Sea since it provides an information that in turn can be used to unravel the climatic and oceanographic patterns that characterised the Western Mediterranean in the past.

\section{Acknowledgements}

We thank two anonymous reviewers for their valuable contribution to improve this manuscript. B Ausín is grateful to Y González and B Hortelano (Department of Environmental Chemistry, IDAEA-CSIC, Barcelona) for their guidance and supervision during the geochemical analyses. We thank G Ercilla and J Salat for their valuable comments and suggestions. All original data in this study necessary to understand, evaluate and replicate this research are accessible via correspondence with the main author, who will willingly make them available for free to anyone upon request.

\section{Funding}

This study was supported by FPU grant AP2010-2559 from the Ministry of Education of Spain awarded to B. Ausín and by the Consolider Ingenio 'GRACCIE' CSD 2007-00067 program, the CGL2011-26493 program and the VACLIODP339 and MINECO CTM2012-38248 projects of the Spanish Ministry of Science and Innovation. 


\section{References}

Ahagon N, Tanaka Y and Ujiié H (1993) Florisphaera profunda, a possible nannoplankton indicator of late Quaternary changes in sea-water turbidity at the northwestern margin of the Pacific. Marine Micropaleontology 22: 255-273.

Álvarez C, Amore FO, Cros L et al. (2010) Coccolithophore biogeography in the Mediterranean Iberian margin. Revista Española de Micropaleontología 42: 359-372.

Bárcena MA, Flores JA, Sierro FJ et al. (2004) Planktonic response to main oceanographic changes in the Alboran Sea (Western Mediterranean) as documented in sediment traps and surface sediments. Marine Micropaleontology 53: 423-445.

Baumann KH and Freitag T (2004) Pleistocene fluctuations in the northern Benguela Current system as revealed by coccolith assemblages. Marine Micropaleontology 52: 195-215.

Baumann KH, Andruleit H, Boeckel B et al. (2005) The significance of extant coccolithophores as indicators of ocean water masses, surface water temperature, and palaeoproductivity: A review. Palaeontologische Zeitschrift 79: 93-112.

Beaufort L, Lancelot Y, Camberlin P et al. (1997) Insolation cycles as a major control of equatorial Indian Ocean primary production. Science 278: 1451-1454.

Berger A (1978) Long-term variations of daily insolation and Quaternary climatic changes. Journal of the Atmospheric Sciences 35: 2362-2367.

Bronk Ramsey C (2008) Deposition models for chronological records. Quaternary Science Reviews 27: 42-60.

Brown M (1998) Ocean Data View 4.0. Oceanography 11: 19-21.

Cacho I, Grimalt JO and Canals M (2002) Response of the Western Mediterranean Sea to rapid climatic variability during the last 50,000 years: A molecular biomarker approach. Journal of Marine Systems 33-34: 253-272.

Cacho I, Grimalt JO, Canals M et al. (2001) Variability of the western Mediterranean Sea surface temperature during the last 25,000 years and its connection with the Northern Hemisphere climatic changes. Paleoceanography 16: 40-52.

Cacho I, Grimalt JO, Pelejero C et al. (1999) Dansgaard-Oeschger and Heinrich event imprints in Alboran Sea paleotemperatures. Paleoceanography 14: 698-705.

Cacho I, Grimalt JO, Sierro FJ et al. (2000) Evidence for enhanced Mediterranean thermohaline circulation during rapid climatic coolings. Earth and Planetary Science Letters 183: 417-429.

Cañellas B, Orfila Förster A, Méndez Incera F-J et al. (2010) Influence of the NAO on the northwestern Mediterranean wave climate. Scientia Marina 74: 55-64.

Cheney RE and Doblar RA (1982) Structure and variability of the alboran sea frontal system. Journal of Geophysical Research: Oceans 87: 585-594.

Colmenero-Hidalgo E, Flores J-A, Sierro FJ et al. (2004) Ocean surface water response to short-term climate changes revealed by coccolithophores from the Gulf of Cadiz (NE Atlantic) and Alboran Sea (W Mediterranean). Palaeogeography, Palaeoclimatology, Palaeoecology 205: 317-336.

Combourieu Nebout N, Turon JL, Zahn R et al. (2002) Enhanced aridity and atmospheric high-pressure stability over the western Mediterranean during the North Atlantic cold events of the past 50 k.y. Geology 30: 863-866.

Coplen TB (1996) Editorial: More uncertainty than necessary. Paleoceanography 11: 369-370.

Cortés Sánchez M, Jiménez Espejo FJ, Simón Vallejo MD et al. (2012) The Mesolithic-Neolithic transition in southern Iberia. Quaternary Research 77: 221-234.

Dafner EV, Boscolo R and Bryden HL (2003) The N:Si:P molar ratio in the Strait of Gibraltar. Geophysical Research Letters 30: 1506 .
Emiliani C (1955) Pleistocene temperatures. Geology 63: 539-578.

Fatela F and Taborda R (2002) Confidence limits of species proportions in microfossil assemblages. Marine Micropaleontology 45: 169-174.

Fenoglio-Marc L, Mariotti A, Sannino G et al. (2013) Decadal variability of net water flux at the Mediterranean Sea Gibraltar Strait. Global and Planetary Change 100: 1-10.

Fletcher WJ and Zielhofer C (2011) Fragility of Western Mediterranean landscapes during Holocene Rapid Climate Changes. CATENA 103: 16-29.

Fletcher WJ, Debret M and Sanchez Goñi MF (2012) Mid-Holocene emergence of a low-frequency millennial oscillation in western Mediterranean climate: Implications for past dynamics of the North Atlantic atmospheric westerlies. The Holocene 23: 153-166.

Flores JA and Marino M (2002) Pleistocene calcareous nannofossil stratigraphy for ODP Leg 177 (Atlantic sector of the Southern Ocean). Marine Micropaleontology 45: 191-224.

Flores JA and Sierro FJ (1997) Revised technique for calculation of calcareous nannofossil accumulation rates. Micropaleontology 43: 321-324.

Flores JA, Bárcena MA and Sierro FJ (2000) Ocean-surface and wind dynamics in the Atlantic Ocean off Northwest Africa during the last 140000 years. Palaeogeography, Palaeoclimatology, Palaeoecology 161: 459-478.

Flores JA, Gersonde R and Sierro FJ (1999) Pleistocene fluctuations in the Agulhas Current Retroflection based on the calcareous plankton record. Marine Micropaleontology 37: 1-22.

Flores JA, Sierro FJ, Francés G et al. (1997) The last 100,000 years in the western Mediterranean: Sea surface water and frontal dynamics as revealed by coccolithophores. Marine Micropaleontology 29: 351-366.

Font J, Palanques A, Puig P et al. (2007) Sequence of hydrographic changes in NW Mediterranean deep water due to the exceptional winter of 2005. Scientia Marina 71: 339-346.

Frigola J, Moreno A, Cacho I et al. (2007) Holocene climate variability in the western Mediterranean region from a deepwater sediment record. Paleoceanography 22: PA2209.

García-Gorriz E and Carr ME (1999) The climatological annual cycle of satellite-derived phytoplankton pigments in the Alboran Sea. Geophysical Research Letters 26: 2985-2988.

García Lafuente J, Álvarez Fanjul E, Vargas JM et al. (2002) Subinertial variability in the flow through the Strait of Gibraltar. Journal of Geophysical Research: Oceans 107: 3168.

García Lafuente J, Sánchez Román A, Díaz del Río G et al. (2007) Recent observations of seasonal variability of the Mediterranean outflow in the Strait of Gibraltar. Journal of Geophysical Research: Oceans 112: C10005.

García Lafuente J, Vargas JM, Plaza F et al. (2000) Tide at the eastern section of the Strait of Gibraltar. Journal of Geophysical Research: Oceans 105: 14197-14213.

Giraudeau J (1992) Distribution of recent nannofossils beneath the Benguela system: Southwest African continental margin. Marine Geology 108: 219-237.

Goy JL, Zazo C and Dabrio CJ (2003) A beach-ridge progradation complex reflecting periodical sea-level and climate variability during the Holocene (Gulf of Almería, Western Mediterranean). Geomorphology 50: 251-268.

Hammer Ø, Harper DAT and Ryan PD (2001) PAST: Paleontological statistics software package for education and data analysis. Palaeontologia Electronica 4: 9.

Heburn GW and La Violette PE (1990) Variations in the structure of the anticyclonic gyres found in the Alboran Sea. Journal of Geophysical Research 95: 1599-1613.

Hernández-Almeida I, Bárcena MA, Flores JA et al. (2011) Microplankton response to environmental conditions in the 
Alboran Sea (Western Mediterranean): One year sediment trap record. Marine Micropaleontology 78: 14-24.

Hurrell JW (1995) Decadal trends in the North Atlantic Oscillation: Regional temperatures and precipitation. Science 269: 676-679.

Incarbona A, Di Stefano E, Patti B et al. (2008) Holocene millennial-scale productivity variations in the Sicily Channel (Mediterranean Sea). Paleoceanography 23: PA3204.

IPCC (2013) Climate Change 2013: The Physical Science Basis. Contribution of Working Group I to the Fifth Assessment Report of the Intergovernmental Panel on Climate Change (ed TF Stocker, D Qin, G-K Plattner et al.) Cambridge and New York: Cambridge University Press, 1535 pp.

Jalut G, Esteban Amat A, Bonnet L et al. (2000) Holocene climatic changes in the Western Mediterranean, from south-east France to south-east Spain. Palaeogeography, Palaeoclimatology, Palaeoecology 160: 255-290.

Jalut G, Esteban Amat A, Riera i, Mora S et al. (1997) Holocene climatic changes in the western Mediterranean: Installation of the Mediterranean climate. Comptes Rendus de l'Académie des Sciences: Series IIA - Earth and Planetary Science 325: 327-334.

Jimenez-Espejo FJ, Martinez-Ruiz F, Sakamoto T et al. (2007) Paleoenvironmental changes in the western Mediterranean since the last glacial maximum: High resolution multiproxy record from the Algero-Balearic basin. Palaeogeography, Palaeoclimatology, Palaeoecology 246: 292-306.

Josey SA, Somot S and Tsimplis M (2011) Impacts of atmospheric modes of variability on Mediterranean Sea surface heat exchange. Journal of Geophysical Research: Oceans 116: C02032.

Leaman KD and Schott FA (1991) Hydrographic structure of the Convection Regime in the Gulf of Lions: Winter 1987. Journal of Physical Oceanography 21: 575-598.

Lionello P (2012) The Climate of the Mediterranean Region: From the Past to the Future. Burlington, MA: Elsevier Science.

Lionello P, Manotte-Rizzoli P and Boscolo R (2006) Relations between variability in the Mediterranean region and midlatitude variability. In: Lionello $\mathrm{P}$, Manotte-Rizzoli $\mathrm{P}$ and Boscolo R (eds) Mediterranean Climate Variability. Amsterdam: Elsevier, pp. 179-226.

McIntyre A and Bé AWH (1967) Modern coccolithophoridae of the Atlantic Ocean: Placoliths and cyrtoliths. Deep Sea Research and Oceanographic Abstracts 14: 561-597.

Marchal O, Cacho I, Stocker TF et al. (2002) Apparent long-term cooling of the sea surface in the northeast Atlantic and Mediterranean during the Holocene. Quaternary Science Reviews 21: 455-483.

Martrat B, Grimalt JO, Lopez-Martinez C et al. (2004) Abrupt temperature changes in the Western Mediterranean over the past 250,000 years. Science 306: 1762-1765.

Mayewski PA, Rohling EE, Curt Stager J et al. (2004) Holocene climate variability. Quaternary Research 62: 243-255.

MEDOCGROUP (1970) Observation of formation of deep water in the Mediterranean Sea, 1969. Nature 227: 1037-1040.

Melki T, Kallel N, Jorissen FJ et al. (2009) Abrupt climate change, sea surface salinity and paleoproductivity in the western Mediterranean Sea (Gulf of Lion) during the last $28 \mathrm{kyr}$. Palaeogeography, Palaeoclimatology, Palaeoecology 279: 96-113.

Mergulhao LP, Guptha MVS, Unger D et al. (2013) Seasonality and variability of coccolithophore fluxes in response to diverse oceanographic regimes in the Bay of Bengal: Sediment trap results. Palaeogeography, Palaeoclimatology, Palaeoecology 371: 119-135.

Mertens C and Schott F (1998) Interannual variability of deepwater formation in the Northwestern Mediterranean. Journal of Physical Oceanography 28: 1410-1424.
Millot C (1999) Circulation in the Western Mediterranean Sea. Journal of Marine Systems 20: 423-442.

Minas HJ, Coste B, Le Corre P et al. (1991) Biological and geochemical signatures associated with the water circulation through the Strait of Gibraltar and in the Western Alboran Sea. Journal of Geophysical Research 96: 8755-8771.

Molfino B and McIntyre A (1990) Precessional forcing of nutricline dynamics in the equatorial Atlantic. Science 249: 766769.

Moreno A, Cacho I, Canals M et al. (2004) Millennial-scale variability in the productivity signal from the Alboran Sea record, Western Mediterranean Sea. Palaeogeography, Palaeoclimatology, Palaeoecology 211: 205-219.

Müller PJ, Kirst G, Ruhland G et al. (1998) Calibration of the alkenone paleotemperature index U37K' based on core-tops from the eastern South Atlantic and the global ocean $\left(60^{\circ} \mathrm{N}-60^{\circ} \mathrm{S}\right)$. Geochimica et Cosmochimica Acta 62: 1757-1772.

Naranjo C, García Lafuente J, Sánchez Garrido JC et al. (2012) The Western Alboran Gyre helps ventilate the Western Mediterranean Deep Water through Gibraltar. Deep Sea Research Part I: Oceanographic Research Papers 63: 157-163.

Okada H and Honjo S (1973) The distribution of oceanic coccolithophorids in the Pacific. Deep Sea Research and Oceanographic Abstracts 20: 355-374.

Okada H and Wells P (1997) Late Quaternary nannofossil indicators of climate change in two deep-sea cores associated with the Leeuwin Current off Western Australia. Palaeogeography, Palaeoclimatology, Palaeoecology 131: 413-432.

Olsen J, Anderson NJ and Knudsen MF (2012) Variability of the North Atlantic Oscillation over the past 5,200 years. Nature Geosciences 5: 808-812.

Paillard D, Labeyrie L and Yiou P (1996) Macintosh program performs time-series analysis. EOS Transactions of the American Geophysical Union 77: 379.

Pérez-Folgado M, Sierro FJ, Flores JA et al. (2003) Western Mediterranean planktonic foraminifera events and millennial climatic variability during the last $70 \mathrm{kyr}$. Marine Micropaleontology 48: 49-70.

Reimer PJ, Bard E, Bayliss A et al. (2013) IntCal13 and Marine13 radiocarbon age calibration curves $0-50,000$ years cal BP. Radiocarbon 55: 1869-1887.

Rixen M, Beckers JM, Levitus S et al. (2005) The Western Mediterranean Deep Water: A proxy for climate change. Geophysical Research Letters 32: L12608.

Roberts N, Moreno A, Valero-Garcés BL et al. (2012) Palaeolimnological evidence for an east-west climate see-saw in the Mediterranean since AD 900. Global and Planetary Change 84-85: 23-34.

Rohling EJ, Den Dulk M, Pujol C et al. (1995) Abrupt hydrographic change in the Alboran Sea (western Mediterranean) around $8000 \mathrm{yrs}$ BP. Deep Sea Research Part I: Oceanographic Research Papers 42: 1609-1619.

Sánchez-Goñi M, Cacho I, Turon J et al. (2002) Synchroneity between marine and terrestrial responses to millennial scale climatic variability during the last glacial period in the Mediterranean region. Climate Dynamics 19: 95-105.

Sarhan T, García Lafuente J, Vargas M et al. (2000) Upwelling mechanisms in the northwestern Alboran Sea. Journal of Marine Systems 23: 317-331.

Siani G, Paterne M, Arnold M et al. (2000) Radiocarbon reservoir ages in the Mediterranean Sea and Black Sea. Radiocarbon 42: $271-280$.

Sierro FJ, Hodell DA, Curtis JH et al. (2005) Impact of iceberg melting on Mediterranean thermohaline circulation during Heinrich events. Paleoceanography 20: PA2019.

Smith RO, Bryden HL and Stansfield K (2008) Observations of new western Mediterranean Deep Water formation using Argo floats 2004-2006. Ocean Science 2: 133-149. 
Stuiver M and Braziunas TF (1993) Modeling atmospheric ${ }^{14} \mathrm{C}$ influences and ${ }^{14} \mathrm{C}$ ages of marine samples to $10,000 \mathrm{BC}$. Radiocarbon 35: 137-189.

Sumner G, Homar V and Ramis C (2001) Precipitation seasonality in eastern and southern coastal Spain. International Journal of Climatology 21: 219-247.

Thierstein HR and Young JR (2004) Coccolithophores: From Molecular Processes to Global Impact. Amsterdam: Springer, $565 \mathrm{pp}$.

Thomson DJ (1990) Time series analysis of Holocene climate data. Philosophical Transactions of the Royal Society of London Series A: Mathematical and Physical Sciences 330: 601-616.

Trigo RM, Pozo-Vázquez D, Osborn TJ et al. (2004) North Atlantic oscillation influence on precipitation, river flow and water resources in the Iberian Peninsula. International Journal of Climatology 24: 925-944.

Trouet V, Esper J, Graham NE et al. (2009) Persistent positive North Atlantic Oscillation mode dominated the medieval climate anomaly. Science 324: 78-80.

Tsimplis MN and Josey SA (2001) Forcing of the Mediterranean Sea by atmospheric oscillations over the North Atlantic. Geophysical Research Letters 28: 803-806.
Vargas-Yáñez M, Plaza F, García-Lafuente J et al. (2002) About the seasonal variability of the Alboran Sea circulation. Journal of Marine Systems 35: 229-248.

Villanueva J, Pelejero C and Grimalt JO (1997) Clean-up procedures for the unbiased estimation of $\mathrm{C} 37$ alkenone sea surface temperatures and terrigenous n-alkane inputs in paleoceanography. Journal of Chromatography A 757: 145-151.

Wanner H, Solomina O, Grosjean M et al. (2011) Structure and origin of Holocene cold events. Quaternary Science Reviews 30: 3109-3123.

Weaver PPE and Pujol C (1988) History of the last deglaciation in the Alboran Sea (western Mediterranean) and adjacent north Atlantic as revealed by coccolith floras. Palaeogeography, Palaeoclimatology, Palaeoecology 64: 35-42.

Zazo C, Goy J-L, Somoza L et al. (1994) Holocene sequence of sea-level fluctuations in relation to climatic trends in the Atlantic-Mediterranean linkage coast. Journal of Coastal Research 10: 933-945.

Ziveri P, Thunell RC and Rio D (1995) Export production of coccolithophores in an upwelling region: Results from San Pedro Basin, Southern California Borderlands. Marine Micropaleontology 24: 335-358. 